\title{
Analisis ekspor pulp dan kertas Jambi ke China
}

\author{
Miko Ramadani*; Siti Hodijah; Dearmi Artis \\ Prodi Ekonomi Pembangunan, Fak Ekonomi dan Bisnis,Universitas Jambi \\ *E-mail korespondensi: mikoramadani8@gmail.com
}

\begin{abstract}
Research objectives to analyze 1). development of paper and pulp exports in Jambi; 2). the significant contribution of pulp and paper export volume to Jambi's total export volume; 3). factors affecting Jambi's pulp and paper exports to China. The method used in this study is descriptive analysis and quantitative analysis, namely multiple regression analysis using data from 2002-2017. The results of this study show 1). The average volume of Jambi's pulp and paper exports to China was 114,280 tons, an increase of 15.26 percent. 2). The average contribution of Jambi's pulp and paper export volume to China to Jambi's total exports is 4.25 percent. 3). Simultaneously, the price, exchange rate, and GDP significantly affect the volume of Jambi's pulp and paper exports to China.
\end{abstract}

Keywords : Pulp, Paper, Price, Exchange Rate, GDP

\begin{abstract}
Abstrak
Tujuan penelitian untuk Menganalisis 1). perkembangan ekspor kertas dan pulp di Jambi; 2). besarnya kontribusi volume ekspor pulp dan kertas terhadap total volume ekspor Jambi; 3). faktor-faktor yang mempengaruhi ekspor pulp dan kertas Jambi ke China. Metode yang digunakan dalam penelitian ini adalah analisis deskriptif dan analisis kuantitatif yaitu analisis regresi berganda dengan menggunakan data tahun 2002-2017. Hasil penelian ini menunjukkan 1). Rata-rata volume ekspor pulp dan kertas Jambi ke China sebesar 114.280 ton atau meningkat sebesar 15,26 persen. 2). Rata-rata kontribusi volume ekspor pulp dan kertas Jambi ke China terhadap total ekspor Jambi sebesar 4,25 persen. 3). Secara simultan harga, kurs, dan GDP berpengaruh signifikan terhadap volume ekspor pulp dan kertas Jambi ke China.Sedangkan secara parsial harga tidak berpengaruh signifikan terhadap volume ekspor pulp dan kertas Jambi ke China.
\end{abstract}

Kata kunci: Pulp, Kertas, Harga, Kurs, GDP.

\section{PENDAHULUAN}

Salah satu kegiatan yang berperan penting dalam perekonomian suatu negara adalah kegiatan perdagangan internasional, sehingga perdagangan internasional harus terus diupayakan untuk dapat meraih berbagai peluang dan kesempatan yang ada. Perdagangan internasional adalah perdagangan baik barang atau jasa yang dilakukan oleh penduduk suatu negara dengan penduduk negara lainnya (Halwani 2002).

Kegiatan perdagangan internasioanl terbagi dua, yaitu ekspor dan impor. Menurut Tan (2014), ekspor merupakan suaru proses aktivitas menjual produk suatu negara ke negara lain yang dilakukan oleh eksportir dengan tujuan mencari keuntungan, meskipun bagi pemerintah sering keuntungan tidak selalu berupa uang, dapat juga keuntungan 
politik dalam upaya memperkuat hubungan ekonomi suatu negara dengan negara lain.

Industri pulp dan kertas adalah industri yang mengolah kayu sebagai bahan dasar untuk memproduksi pulp, kertas, papan, dan produk berbasis selulosa lainnya (wikipedia). Salah satu industri memiliki prospek yang cerah di masa mendatang yang dapat memberikan kontribusi yang cukup besar dalam perekonomian Indonesia. Dengan latar belakang Indonesia yang merupakan daerah hutan hujan tropis yang dapat mendukung ketersediaan bahan baku untuk industri pulp dan kertas, terlebih lagi melalui keberadaan Hutan Tanaman Industri (HTI) dapat mendorong pertumbuhan industri pulp dan kertas Indonesia. Selain itu juga tersedianya sumber daya manusia (SDM) untuk melakukan proses produksi secara efisien yang disertai dengan biaya upah yang relatif rendah turut mendukung berkembangnya industri pulp dan kertas Indonesia.

Selama ini sebagian besar ekspor pulp dan kertas Indonesia ditujukan ke negara - negara di Asia. Negata tujuan utama ekspor pulp antara lain Cina, Korea Selatan, dan Jepang. Sedangkan negara tujuan utama untuk ekspor kertas antara lain RRC, Korea Selatan, Singapura, Malaysia, Hongkong, dan Taiwan. Selama ini ekspor pulp Indonesia belum mencapai ke negara-negara yang memiliki tingkat konsumsi pulp dan kertas terbesar di dunia seperti negara-negara di Amerika Utara dan Scandinavia (NORSCAN). Hal tersebut disebabkan, antara lain karena kualitas pulp Indonesia masih lebih rendah dibandingkan kualitas pulp yang diproduksi oleh negara-negara NORSCAN.

Jambi adalah salah satu daerah yang mengandalkan kegiatan perdagangan internasional sebagai penggerak dalam pertumbuhan ekonomi. Selain berperan dalam mendatangkan Pendapatan Daerah, dengan melakukan perdagangan internasional maka akan membangun jaringan bisnis global dan bisa selalu mengikuti perkembangan produk dan industri di pasar internasional. Salah saTu perdaganan internasional tersebut adalah ekspor.

Dalam ekspor Jambi terdapat tiga sektor yang berperan penting yaitu sektor industri, sektor pertanian, dan sektor pertambangan. Jumlah ekspor yang paling besar kontribusinya selama tahun 2013-2017 adalah sektor pertambanganan. dimana sektor pertambangan rata-rata memberikan kontribusi sebesar 55,89 persen dari jumlah ekspor Jambi, sektor industri cukup besar kontribusinya terhadap total ekspor Jambi dimana rata-rata kontribusinya sebesar 40,65 persen dan sektor pertanian sebesar 3,46 persen. Berdasarkan dari data tersebut diketahui bahwa walaupun sektor industri merupakan sektor kedua yang berkontribusi dalam jumlah ekspor Jambi, tetapi sektor ini merupakan sektor yang cukup potensial dalam penunjang perekonomian dan pendapatan daerah Provinsi Jambi.

Untuk wilayah Jambi Industri bubur kertas (pulp) dan kertas merupakan salah satu hasil dari sektor industri pada komoditi non migas yang memiliki peranan penting dalam perekonomian Jambi. Industri ini memberikan kontribusi yang cukup besar terhadap Pendapatan daerah, karna menjadi 3 komoditi terbesar dalam ekspor provinsi Jambi.

Industri pulp dan kertas di Jambi terus berkembang seiring dengan permintaan akan jumlah ekspor pulp dan kertas, berdasarkan Bank Indonesia cabang Jambi (2017), menunjukkan bahwa ekspor pulp dan kertas provinsi Jambi berfluktuasi, nilai ekspor pulp dan kertas cendrung terus meningkat kecuali pada tahun 2014, pada tahun 2013 nilai ekpor pulp dan kertas Jambi sebesar US\$112.730 ribu, pada tahun 2014 mengalami penurunan sebesar $-0,96$ persen dari tahun sebelumnya atau sebesar US\$ 111.648 ribu, pada tahun 2015 mengalami kenaikan sebesar 25,26 persen dari 
tahun sebelumnya atau sebesar US\$ 139.8556 ribu. Tahun 2016 dan 2017 nilai ekspor pulp dan kertas Jambi mengalami peningaktan mencapai US\$ 143,643 ribu dan US\$ 154,865 ribu atau sebesar 2,70 persen dan 7,81 persen dari tahun sebelumnya.

China merupakan pemasok utama pulp dan kertas dunia, disamping untuk kebutuhan konsumsi, juga sebagai bahan untuk memproduksi berbagai produk turunan yang lainnya. Dewasa ini, China sangat sulit sekali untuk meningkatkan kapasitas produksi kertas karena keterbatasan lahan (area) untuk mengusahakan pasokan bahan baku serpih (chipeoof) bagi industri kertas.

Dalam perdagangan internasional terutama pada kegiatan ekspor, salah satu yang dapat mempengaruhi tinggi rendahnya ekspor pulp dan kertas yaitu harga. Harga adalah sejumlah uang yang dibebankan atas suatu produk atau jasa atau jumlah dari nilai yang ditukar konsumen atas manfaatmanfaat karena menggunakan atau memiliki produk atau jasa tersebut (Kotler, 2001). Harga yang ditawarkan berhubungan secara negatif dengan jumlah yang diminta atau dengan kata lain semakin besar harga komoditi maka akan lebih sedikit kualitas komoditi tersebut yang minta. sebaliknya harga berhubungan secara positif dengan penawaran. Semakin tinggi harga maka akan semakin banyak kuantitas yang ditawarkan.

Menurut Nopirin (1996) kurs adalah pertukaran antara dua mata uang yang berbeda, maka akan mendapat perbandingan nilai/harga antara kedua mata uang tersebut. Dalam pengertian sederhana, kurs berarti jumlah suatu mata uang yang diperlukan untuk membeli suatu satuan mata uang lain. Misalnya kurs dollar terhadap rupiah sama dengan jumlah rupiah yang diperlukan untuk membeli suatu dollar Amerika Serikat (Haryadi, 2007). depresiasi atau apresiasi dalam nilai mata uang akan mengakibatkan perubahan terhadap ekspor maupun impor. Jika nilai tukar mengalami depresiasi, yaitu nilai mata uang dalam negeri menurun dan berarti mata uang asing bertambah tinggi (harganya) akan menyebakan ekspor meningkatan dan impor cenderung menurun. Jadi kurs valuta asing memiliki hubungan yang searah dengan volume ekspor. jadi nilai tukar dolar naik, maka volume ekspor juga akan meningkat (Sukirno, 2004).

Menurut Sukirno (2008) pendapatan nasional dimaksudkan untuk menyatakan nilai barang dan jasa yang dihasilkan dalam suatu negara. Dengan demikian dalam konsep tersebut istilah pendapatan nasional adalah mewakili arti Gross Domestic Product dan Gross National Product. salah satu indikator kemajuan ekonomi suatu negara adalah Pendapatan Nasional. Semakin besar Pendapatan Nasional maka semakin maju ekonomi suatu negara, karena Pendapatan Nasional membawa pengaruh positif terhadap ekspor (Tan, 2014).

Berdasarkan latar belakang tersebut, penelitian ini bertujuan untuk menganalisis: 1) Perkembangan ekspor pulp dan kertas Jambi ke China, 2) Berapa besar kontribusi volume ekspor pulp dan kertas terhadap total volume ekspor Jambi, dan 3) Faktor-faktor apa yang mempengaruhi ekspor pulp dan kertas Jambi ke China

\section{METODE}

Data yang digunakan dalam penelitian ini adalah data sekunder, dalam rentang waktu tahun 2002-2017 yang meliputi data volume ekspor pulp dan kertas Jambi ke China, data harga pulp dan kertas, data nilai tukar rupiah, data GDP China. Sumber data yang digunakan dalam penelitian ini berasal dari : Badan Pusat Statistik Provinsi Jambi, Bank Indonesia Cabang Jambi, Asosiasi Pulp dan Kertas Indonesia (APKI), PT Lontar Papyrus Pulp \& Paper dan Asian Development Bank. 
Untuk menjawab rumusan masalah pertama besarnya perkembangan diketahui dengan menggunakan rumus berikut :

$$
G E(X)=\frac{(X)_{t}-(X)_{t-1}}{(X)_{t-1}} \times 100
$$

dimana :

$G E(X) \quad=$ Perkembangan variabel (ekspor, GDP China, nilai tukar dan harga pulp dan kertas Jambi) tahun t (sekarang)

$X_{t} \quad=$ Nilai variabel (ekspor, GDP China, nilai tukar dan harga pulp dan kertas Jambi) tahun $\mathrm{t}$ (sekarang)

$X_{t-1}=$ Nilai variabel (ekspor, GDP China, nilai tukar dan harga pulp dan kertas Jambi) $t-1$ (lalu)

Untuk menjawab permasalahan yang ke dua untuk menghitung kontribusi, menggunakan rumus berikut :

$$
\text { KE_t }(\%)=\frac{V E_{-t}}{T V_{-t}} \times 100 \%
$$

Dimana :

KE_t $=$ Kontirbusi ekspor pulp dan kertas tahun $\mathrm{t}$

$V E_{-t}=$ Volume ekspor pulp dan kertas tahun $\mathrm{t}$

$T V_{-t}=$ Total komoditi industri tahun

Untuk menjawab permasalahan yang ke tiga, yaitu untuk mengetahui faktorfaktor yang mempengaruhi volume ekspor pulp dan kertas dalam hal ini menggunakan model persamaan regresi linear berganda dengan rumus sebagai beriku (Gujarati, 2003

$$
\mathrm{VE}=\beta_{\circ}+\beta_{1} P d+\beta_{2} E R+\beta_{3} P r+e_{i}
$$

Dimana :

VE $=$ Volume ekspor pulp dan kertas jambi

$\beta_{o} \quad=$ Konstanta

$\beta_{i} \quad=$ Koefisien regresi

$\mathrm{Pd}=$ GDP China

$E R \quad=$ Nilai tukar rupiah per dollar

$\operatorname{Pr} \quad=$ Harga pulp dan kertas jambi

$e_{i} \quad=$ Standar error

\section{HASIL DAN PEMBAHASAN}

\section{Perkembangan volume ekspor pulp dan kertas Jambi ke China}

Perkembangan volume ekspor pulp dan kertas Jambi ke China tahun 2002-2017 memiliki rata-rata peningkatan sebesar 15,26 persen. Berdasarkan pada Tabel 1 terlihat bahwa Tahun 2002 volume ekspor pulp dan kertas Jambi ke China sebesar 30.565 ton pada tahun 2003-2006 volume ekspor mengalami tren peningkatan terus menerus hingga tahun 2006 mencapai 69.245 ton atau sebesar 5,31 persen dari tahun sebelumnya. Tahun 2007 volume ekspor pulp dan kertas Jambi ke China mengalami penurunan sebesar $-5,03$ persen dari tahun sebelumnya atau sebesar 65.767 ton. Namun 
pada tahun 2008 dan 2009 mengalami kenaikan yaitu sebesar 70.521 ton dan 80.685 ton atau meningkat sebesar 9,78 persen dan 4,24 persen dari tahun sebelumnya. Akan tetapi pada tahun 2010 kembali mengalami penurunan sebesar $-3,77$ persen dari tahun sebelumnya atau sebesar 77.640 ton. Tahun 2011 hingga tahun 2015 volume ekspor.

Pulp dan kertas Jambi ke China kembali mengalami peningkatan, hingga pada tahun 2015 mencapai 210.379 ton atau sebesar 19,44 persen dari tahun seabelumnya. Namun tahun 2016-2017 volume ekspor pulp dan kertas Jambi ke China penurunan berturut-turut yaitu sebesar -3.02 persen dan -2.93 persen dari tahun sebelumnya atau sebesar 204.030 ton dan 198.045 ton. Secara lebih terperinci dapat dilihat pada Tabel 1.

Tabel 1. Perkembangan volume ekspor pulp dan kertas periode 2002-2017

\begin{tabular}{ccc}
\hline Tahun & Volume (Ton) & Perkembangan \\
\hline 2002 & 30.565 & - \\
2003 & 39.565 & 29,45 \\
2004 & 55.788 & 41,00 \\
2005 & 65.754 & 17,86 \\
2006 & 69.245 & 5,31 \\
2007 & 65.767 & $-5,02$ \\
2008 & 70.521 & 7,23 \\
2009 & 80.685 & 14,41 \\
2010 & 77.640 & $-3,77$ \\
2011 & 148.308 & 91,02 \\
2012 & 162.362 & 9,48 \\
2013 & 173.688 & 6,98 \\
2014 & 176.132 & 1,41 \\
2015 & 210.379 & 19,44 \\
2016 & 204.030 & $-3,02$ \\
2017 & 198.045 & $-2,93$ \\
\hline Rata - rata & $\mathbf{1 1 4 . 2 8 0}$ & $\mathbf{1 5 , 2 6}$
\end{tabular}

Sumber: PT. Lontar Papyrus Pulp dan Paper Industry, 2018 (diolah)

\section{Perkembangan harga pulp dan kertas}

Harga ekspor pulp dan kertas tertinggi terjadi pada tahun 2017 dengan pertumbuhan 9.65 persen atau sebesar $\mathrm{Rp} 9.353,-/ \mathrm{Kg}$ dari tahun sebelumnya. Harga eksport pulp dan kertas yang terendah terjadi pada tahun 2002 sebesar Rp 3.887,-/kg. Dari Tabel 2 terlihat bahwa dari tahun ketahun harga ekspor pulp dan kertas Jambi mengalami fluktuasi. Titik tertinggi perkembangan harga ekspor pulp dan kertas Jambi terjadi pada tahun 2005 dimana perkembangan harga ekspor sebesar 80,47 persen. Titik terendah dari tabel tersebut terjadi pada tahun 2009 dimana perkembangan harga ekspor pulp dan kertas Jambi sebesar -28,53 persen. Rata-rata harga ekspor pulp dan kertas Jambi sebesar Rp 6.627 atau perkembanganya sebesar 9.65 persen.

Tahun 2002 harga ekspor pulp dan kertas sebesar Rp 3.389,-/Kg, kemudian tahun 2003 harga ekspor pulp dan kertas mengalami peningkatan yaitu sebesar 10,13 persen atau sebesar Rp 3.733,-/kg. Pada tahun 2004 mengalami penurunan yaitu sebesar 3,53 persen atau sebesar Rp 3.601,-/kg. Pada tahun 2005-2006 harga ekspor pulp dan kertas kembali meningkat yaitu sebesar 80,47 persen dan 25,64 persen atau sebesar Rp $6.499,-/ \mathrm{kg}$ dan Rp 8.165,-/kg. tahun 2007 hingga tahun 2012 harga ekspor pulp dan kertas mengalami fluktuasi setiap tahun, hingga tahun 2012 harga ekspor pulp dan kertas meningkat sebesar 2,68 persen atau sebesar Rp 6.119,-/Kg. Tahun 2013 
meningkat sebesar 36,53 persen atau sebesar $\mathrm{Rp} 8.354,-/ \mathrm{Kg}$ namun pada tahun 20142017 kembali mengalami fluktuasi setiap tahun, hingga tahun 2017 meningakat sebesar 9,47 persen atau sebesar Rp9.353,-/Kg.

Tabel 2. Perkembangan harga ekspor pulp dan kertas periode 2002-2017

\begin{tabular}{ccc}
\hline Tahun & Harga Ekspor $(\mathbf{R p} / \mathbf{K g})$ & Perkembangan (\%) \\
\hline 2002 & Rp3.389 & - \\
2003 & Rp3.733 & 10,13 \\
2004 & Rp3.601 & $-3,53$ \\
2005 & Rp6.499 & 80,47 \\
2006 & Rp8.165 & 35,64 \\
2007 & Rp6.665 & $-18,37$ \\
2008 & Rp7.032 & 5,50 \\
2009 & Rp5.026 & $-28,53$ \\
2010 & Rp6.645 & 32,23 \\
2011 & Rp5.959 & $-10,32$ \\
2012 & Rp6.119 & 2,68 \\
2013 & Rp8.354 & 36,53 \\
2014 & Rp8.079 & $-3,29$ \\
2015 & Rp8.868 & 9,76 \\
2016 & Rp8.543 & $-3,66$ \\
2017 & Rp9.353 & 9,47 \\
\hline Rata-rata & Rp6.627 & $\mathbf{9 , 6 5}$ \\
\hline
\end{tabular}

umber : Asosiasi Pulp dan Kertas Indonesia (APKI), 2018 (diolah)

\section{Perkembangan nilai tukar}

Nilai tukar atau yang dikenal dengan kurs merupakan perbandingan antara harga mata uang suatu negara dengan mata uang negara lain. Pentingnya peranan nilai tukar mata uang baik di negara maju maupun di negara berkembang, berbagai upaya dilakukan di suatu negara untuk menjaga posisi nilai tukar mata uang agar selalu berada dalam keadaan yang relatif stabil, kestabilan nilai tukar mata uang juga dipengaruhi oleh sistem nilai tukar yang di anut oleh negara tersebut. Negara berkembang seperti Indonesia ini menunjukkan bahwa tingkat stabilitas mata uang rupiah merupakan variabel yang paling sensitif terhadap akar permasalahan utama dalam perkembangan perekonomian.

Berdasarkan Tabel 3 dapat dilihat fluktuasi nilai tukar rupiah terhadap dolar Amerika tahun 2002-2017 diperoleh hasil sebagai berikut: Rata - rata perkembangan nilai tukar rupiah terhadap dolar Amerika ialah sebesar 3,26 persen. Apresiasi tertinggi nilai tukar rupiah terhadap dolar Amerika adalah pada tahun 2009 dimana nilai tukar rupiah terhadap dolar Amerika adalah sebesar Rp 9.400/US\$ dimana sebelumnya nilai tukar rupiah terhadap dolar Amerika adalah Rp 10.950/US\$. Dimana rupiah mengalami apresiasi sebesar Rp 1.550,- atau 14,16 persen.

Depresiasi tertinggi nilai tukar rupiah terhadap dolar Amerika yaitu pada tahun 2013 dimana nilai tukar rupiah terhadap dolar Amerika adalah Rp 12.189,- dari sebelumnya nilai tukar rupiah terhadap dolar Amerika sebesar Rp 9.670 pada tahun 2012. Hal ini menunjukkan Nilai Tukar rupiah mengalami depresiasi sebesar Rp 2.519,terhadap dolar Amerika atau sebesar 26,05 persen. 
Pada tahun 2002 nilai tukar rupiah terhadap dolar Amerika sebesar Rp 8.940,namun pada tahun 2003 nilai tukar rupiah terapresiasi sebesar 5,31 persen atau sebesar Rp 8.465,- . tahun 2004 sampai tahun 2005 nilai tukar rupiah terhadap dolar Amerika terdepresiasi sebesar 9,75 persen dan 5,81 persen atau sebesar Rp 9.290,- dan Rp 9.830,- . Namun tahun 2006 kembali tukar rupiah terhadap dolar Amerika terapresiasi sebesar 8,24 persen atau sebesar Rp 9.020,- .

Tabel 3. Perkembanga nilai tukar rupiah terhadap Dolar Amerika periode 2002-2017

\begin{tabular}{ccc}
\hline Tahun & Kurs (rupiah) & Perkembangan $(\%)$ \\
\hline 2002 & 8.940 & - \\
2003 & 8.465 & $-5,31$ \\
2004 & 9.290 & 9,75 \\
2005 & 9.830 & 5,81 \\
2006 & 9.020 & $-8,24$ \\
2007 & 9.419 & 4,42 \\
2008 & 10.950 & 16,25 \\
2009 & 9.400 & $-14,16$ \\
2010 & 8.991 & $-4,35$ \\
2011 & 9.068 & 0,86 \\
2012 & 9.670 & 6,64 \\
2013 & 12.189 & 26,05 \\
2014 & 12.440 & 2,06 \\
2015 & 13.795 & 10,89 \\
2016 & 13.436 & $-2,60$ \\
2017 & 13.548 & 0,83 \\
\hline Rata-rata & $\mathbf{1 0 . 5 2 8}$ & $\mathbf{3 , 2 6}$ \\
\hline
\end{tabular}

Sumber: Asian Development Bank, 2018(diolah)

Tahun 2007 dan 2008 nilai tukar rupiah terhadap dolar Amerika sebesar Rp 9.419 dan Rp 10.950,- atau terdepresiasi sebesar 4.42 persen dan 16,25 persen dari tahun sebelumnya. Selanjutya tahun 2009 dan tahun 2010 nilai tukar rupiah terhadap dolar Amerika terapresiasi sebesar Rp 9.400,- dan Rp 8.991,- . Hingga tahun 2015 nilai tukar rupiah terhadap dolar Amerika mengalami depresiasi yang panjang hingga mencapai Rp 13.795,- atau sebesar 10,89 persen. Tahun 2016 terapresiasi kembali sebesar 2.60 persen dari tahun sebelumnya atau sebesar Rp 13.436,- , dan di akhir tahun 2017 nilai tukar rupiah terhadap dolar Amerika mengalami depresiasi sebesar 0.83 persen atau sebesar Rp 13.548 ,-.

\section{Perkembangan GDP China}

GDP China periode tahun 2002-2017 cendrung meningkat setiap tahunnya, ratarata GDP China sebesar 71.742 miliar Rupiah dari tahun 2002-2017, peningkatan tertinggi GDP China terjadi pada tahun 2008 yaitu meningkat sebesar 49,87 persen dari tahun sebelumnya atau sebesar 50.416 miliar rupiah, sedangkan penurunan GDP China dalam kurun waktu 2002-2017 terjadi hanya dua kali, yaitu tahun 2009 dan 2016 yaitu sebesar 4,51 persen dan 2,64 persen dari tahun sebelumnya atau sebesar 48.143 miliar rupiah dan 150.776 miliar rupiah. Secara lebih terperinci dapat dilihat pada Tabel 4.

Tabel 4. Perkembangan GDP China periode 2002-2017 


\begin{tabular}{ccc}
\hline Tahun & GDP (miliar rupiah) & Perkembangan (\%) \\
\hline 2002 & 13.208 & \\
2003 & 14.145 & 7,09 \\
2004 & 18.266 & 29,13 \\
2005 & 22.695 & 24,25 \\
2006 & 25.024 & 10,26 \\
2007 & 33.639 & 34,43 \\
2008 & 50.416 & 49,87 \\
2009 & 48.143 & $-4,51$ \\
2010 & 54.542 & 13,29 \\
2011 & 68.210 & 25,06 \\
2012 & 82.875 & 21,50 \\
2013 & 117.441 & 41,71 \\
2014 & 131.049 & 11,59 \\
2015 & 154.865 & 18,17 \\
2016 & 150.776 & $-2,64$ \\
2017 & 162.576 & 7,83 \\
\hline Rata-rata & $\mathbf{7 1 . 7 4 2}$ & $\mathbf{1 9 , 1 4}$
\end{tabular}

Sumber : Asian Development Bank 2018(diolah)

Kontribusi volume ekspor pulp dan kertas terhadap total volume ekspor Jambi

Kontribusi adalah sumbangan yang dapat diberikan oleh suatu hal terhadap hal lain, Kontribusi juga biasa dikenal dengan peranan, kontribusi yang dimaksud dalam penelitian ini adalah sumbangan volume ekspor pulp dan kertas Jambi ke China terhadap total volume ekspor Jambi. berikut merupakan hasil kontribusi volume ekspor pulp dan kertas Jambi ke China terhadap total volume ekspor Jambi.

Tabel 5. Kontribusi volume ekspor pulp dan kertas terhadap total volume ekspor Jambi

\begin{tabular}{cccc}
\hline Tahun & $\begin{array}{c}\text { Volume ekspor } \\
\text { (ton) }\end{array}$ & Total volume (ton) & Kontibusi(\%) \\
\hline 2002 & 30.566 & 1.066 .635 & 2,87 \\
2003 & 39.566 & 1.181 .963 & 3,35 \\
2004 & 55.788 & 970.630 & 5,75 \\
2005 & 65.755 & 710.334 & 9,26 \\
2006 & 69.245 & 1.289 .538 & 5,37 \\
2007 & 65.767 & 1.418 .896 & 4,64 \\
2008 & 70.522 & 1.477 .799 & 4,77 \\
2009 & 80.685 & 1.410 .403 & 5,72 \\
2010 & 77.640 & 2.505 .527 & 3,10 \\
2011 & 148.309 & 4.980 .973 & 2,98 \\
2012 & 162.362 & 5.652 .244 & 2,87 \\
2013 & 173.689 & 4.176 .137 & 4,16 \\
2014 & 176.133 & 6.993 .438 & 2,52 \\
2015 & 210.380 & 7.071 .358 & 2,98 \\
2016 & 204.030 & 6.428 .193 & 3,17 \\
2017 & 198.045 & 4.320 .284 & 4,58 \\
\hline Rata-rata & $\mathbf{1 1 4 . 2 8 0}$ & $\mathbf{3 . 2 2 8 . 3 9 7}$ & $\mathbf{4 , 2 5}$ \\
\hline Sumber: Badan Pusat Statistik Provinsi Jambi $2018($ diolah) &
\end{tabular}


Berdasarkan Tabel 5. dilihat bahwa rata-rata kontribusi ekspor pulp dan kertas Jambi ke China terhadap ekspor Jambi dari tahun 2002-2017 sebesar 4.25 persen, dimana kontibusi pulp dan kertas Jambi ke China terhadap ekspor Jambi terbesar terjadi pada tahun 2005 yaitu 9.26 persen, sedangkan kontribusi terendah terjadi pada tahun 2015, dimana kontribusinya hanya sebesar 2.25 persen

\section{Faktor - faktor yang mempengaruhi ekspor Pulp dan Kertas Jambi ke China}

Pengujian ini menggunakan regresi linier berganda untuk mengetahui seberapa besar pengaruh variabel bebas terhadap variabel terikat. Pengujian ini menggunakan aplikasi Eviews 9, Berdasarkan hasil pengujian statistik diperoleh model persamaan regresi sebagaimana berikut :Estimasi faktor - faktor yang Mempengaruhi Ekspor Pulp dan Kertas Jambi ke China. Berdasarkan Tabel 6 menjelaskan bahwa Nilai konstanta sebesar 133.681,8 ton hal ini menunjukan bahwa jika harga, kurs, dan GDP adalah nol atau tidak berubah maka volume ekspor pulp dan kertas Jambi ke China meningkat sebesar 133.681,8 ton dengan asumsi jika variabel lain tidak berubah atau tetap.

Tabel 6. Hasil pengujian regresi linier berganda

\begin{tabular}{lrlrl}
\hline \hline \multicolumn{1}{c}{ Variable } & Coefficient & Std. Error & t-Statistic & Prob. \\
\hline \hline C & 133681.8 & 50271.39 & 2.659202 & 0.0208 \\
Harga & 1.619248 & 3.648622 & 0.443797 & 0.6651 \\
Kurs & -13.30577 & 6.195784 & -2.147553 & 0.0529 \\
GDP & $1.53 \mathrm{E}-09$ & $2.17 \mathrm{E}-10$ & 7.076147 & 0.0000 \\
\hline \hline & & & \\
R-squared & 0.948762 & Mean dependent var & 114280.1 \\
Adjusted R-squared & 0.935952 & S.D. dependent var & 64428.60 \\
S.E. of regression & 16305.35 & Akaike info criterion & 22.44869 \\
Sum squared resid & $3.19 \mathrm{E}+09$ & Schwarz criterion & 22.64184 \\
Log likelihood & -175.5895 & Hannan-Quinn criter. & 22.45858 \\
F-statistic & 74.06691 & Durbin-Watson stat & 1.577296 \\
Prob(F-statistic) & 0.000000 & & \\
\hline \hline
\end{tabular}

Sumber: Data diolah, 2018

Bedasarkan hasil pengujian table 6 maka dapat ditulis persamaan regresi sebagai berikut :

$$
\begin{aligned}
\mathrm{VE}= & \beta_{o}+\beta_{1} P d+\beta_{2} E R+\beta_{3} P r+e_{\bar{i}} \\
& 133681.8+1.619248-13.30577+1.53 \mathrm{E}-09
\end{aligned}
$$

Koefisien harga ekspor pulp dan kertas sebesar 1.619248, hal ini menunjukan jika terjadi penurunan harga sebesar 1 rupiah maka volume ekspor pulp dan kertas Jambi ke China akan meningkat sebesar 1.619248 ton dengan asumsi jika variabel lain tidak berubah atau tetap.

Koefisien nilai tukar (kurs) rupiah per dollar Amerika sebesar 13,30577, hal ini menunjukan jika terjadi peningkatan sebesar 1 rupiah maka volume ekspor ekspor pulp 
dan kertas Jambi ke China akan menurun sebesar 13,30577 ton dengan asumsi jika variabel lain tidak berubah atau tetap.

Koefisien GDP sebesar 1.53E-09, hal ini menunjukan jika terjadi peningkatan sebesar 1 miliar rupiah maka volume ekspor ekspor pulp dan kertas Jambi ke China akan meningkat sebesar 1.53E-09 ton dengan asumsi jika variabel lain tidak berubah atau tetap.

Dari hasil pengujian diperoleh nilai $F_{\text {hitung }}$ sebesar 74.06, sedangkan $\mathrm{F}$ table sebesar 5.95 dengan demikian nilai $F_{\text {hitung }}(74,06)>$ nilai $F$ tabel $(2,61)$ dan dilihat dari probabilita sebesar $0.000000<\alpha=10$. Artinya secara bersama-sama (simultan) harga pulp dan kertas, nilai tukar dan GDP China berpengaruh signifikan terhadap volume ekspor pulp dan kertas Jambi ke China. Pengujian ini membuktikan bahwa jika secara bersama-sama variabel bebas di perhatikan dengan baik maka akan berpengaruh signifikan terhadap volume ekspor pulp dan kertas Jambi ke China.

Melihat hasil setiap variabel bebas terhadap variabel terikat secara parsial yang diuji dengan uji-t secara rinci dapat dilihat sebagai berikut :

\section{Variabel harga}

Uji t-statistik untuk variabel Harga terhadap volume ekspor pulp dan kertas Jambi ke China secara parsial diketahui $t_{\text {hitung }}(0.443797)<\mathrm{t}$ tabel $(1.35622)$ maka Ho diterima dan Ha ditolak, hal ini berarti bahwa variabel Harga tidak berpengaruh signifikan terhadap volume ekspor pulp dan kertas Jambi ke China.

\section{Variabel kurs}

Uji t-statistik untuk variabel kurs terhadap volume ekspor pulp dan kertas Jambi ke China secara parsial diketahui $t_{\text {hitung }}(2.147553)>t$ tabel (1.35622) maka Ho ditolak dan Ha diterima, hal ini berarti bahwa variabel kurs berpengaruh signifikan terhadap volume ekspor pulp dan kertas Jambi ke China.

\section{Variabel GDP}

Uji t-statistik untuk variabel GDP terhadap volume ekspor pulp dan kertas Jambi ke China secara parsial diketahui $t_{\text {kitung }}(7.076147)>t$ tabel (1.35622) maka Ho ditolak dan Ha diterima, hal ini berarti bahwa variabel GDP berpengaruh signifikan terhadap volume ekspor pulp dan kertas Jambi ke China.

Hasil pengujian diperoleh nilai koefisien determinasi $\left(R^{2}\right)$ sebesar 0.948762 . Hal ini menunjukkan bahwa harga, kurs, dan GDP mampu mempengaruhi volume ekspor Pulp dan kertas Jambi ke China sebesar 94,87 persen, sedangkan sisanya sebesar 5,13 persen dipengaruhi oleh variable lain yang tidak termasuk dalam penelitian ini. Terbukti bahwa harga, kurs, dan GDP mempengaruhi volume ekspor Pulp dan kertas Jambi ke China.

\section{KESIMPULAN DAN SARAN}

\section{Kesimpulan}

Perkembangan volume ekspor pulp dan kertas Jambi ke China selama periode 2002-2017 mengalami fluktuasi disetiap tahunnya, rata-rata volume ekspor pulp dan kertas Jambi ke China sebesar 114.280 ton. Perkembangan volume ekspor pulp dan 
kertas Jambi ke China tertinggi terjadi pada tahun 2011 sebesar 91,02 persen. Perkembangan volume ekspor pulp dan kertas Jambi ke China terendah terjadi pada tahun 2007 sebesar $-5,02$ persen.

Kontribusi volume ekspor pulp dan kertas Jambi ke China terhadap total ekspor Jambi periode 2002-2017 mengalami fluktuasi disetiap tahunnya, rata-rata kontribusi volume ekspor pulp dan kertas Jambi ke China terhadap total ekspor Jambi sebesar 4,25 persen, kontribusi tertinggi terjadi pada tahun 2006 yaitu sebesar 9,26 persen dan kontribusi terendah terjadi pada tahun 2015 yaitu hanya sebesar 2.52 persen dari total ekspor Jambi.

Faktor - faktor yang mempengaruhi ekspor pulp dan kertas Jambi ke China berdasarkan hasil regresi linier berganda, variabel Kurs dan GDP berpengaruh signifikan hal ini dilihat dari $t_{\text {hitung }}>\mathrm{t}$ tabel, sedangkan variabel harga tidak signifikan hal ini dilihat dari $t_{\text {hitung }}<\mathrm{t}$ tabel.

\section{Saran}

Untuk meningkatkan volume ekspor pulp dan kertas Jambi ke China yang harus dilakukan oleh perusahaan adalah meningkatkan mutu produk baik dari bahan baku, sumber daya manusia, dan teknologi yang digunakan. Selanjutnya untuk meningkat kontribusi ekspor pulp dan kertas Jambi ke China terhadap total ekspor jambi adalah dengan meningkatkan volume ekspornya agar dapat meningakatkan perekonomian Jambi.

Setelah melakukan pengujian secara individu dan bersama-sama terhadap keseluruhan variabel berpengaruh terhadap ekspor pulp dan kertas Jambi ke China. Maka hal yang harus dilakukan oleh pemerintah adalah memberikan kebijakan dalam jangka panjang dengan memberikan dukungan terhadap arus perdagangan internasional produk pulp dan kertas, memberikan kemudahan terhadap para investor sehingga akan mendorong pertumbuhan ekonomi.

\section{DAFTAR PUSTAKA}

Asian Development Bank.(2018). Indonesia key indicators. Asian Development Bank.

Badan Pusat Statistik.(2002-2017).Data ekspor pulp dan kertas. Jambi Dalam Angka: Jambi

Gujarati, Damodar.(2003). Economectric. Erlangga: Jakarta

Halwani, H. (2002). Ekonomi internasional dan globalisasi ekonomi. Ghallia

Haryadi.(2007). Ekonomi internasional teori buku kedua lalu-lintas moneter dan kerjasama ekonomi. Biografika: Bogor.

Indonesia: Jakarta

Kotler, Phillip.(2001). Manajemen pemasaran di Indonesia. Jakarta: Salemba Empat.

M Mustika, H Haryadi, \& S Hodijah. (2015).Pengaruh Ekspor dan Impor Minyak Bumi terhadap Pertumbuhan Ekonomi Indonesia, Jurnal Perspektif Pembiayaan dan Pembangunan Daerah, 2 (3), 107-118

Nopirin.(1996). Bisnis Internasional. BPFE: Yogyakarta

Sukirno, Sadono.(2004). Makro ekonomi modern. PT. Raja Grafindo Persada: Jakarta.

Sukirno, Sadono.(2008). Makro ekonomi teori pengantar. PT. Raja Grafindo Persada: Jakarta. 
T Yudiarti, E Emilia, C Mustika. (2018).Pengaruh utang luar negeri, tingkat suku bunga dan neraca transaksi berjalan terhadap nilai tukar Rupiah terhadap Dolar Amerika Serikat, e-Jurnal Perdagangan Industri dan Moneter 6 (1), 14-22

Tan, Syamsurijal.(2014). Ekonomi internasional. Citra Pratama: Jambi.

Wikipedia.(2018). Industri pulp dan kertas, online, https://id.wikipedia.org/wiki/ Industri_pulp_dan_kertas. diakses 10 Agustus 2018 